\title{
The Concrete Notion of the Ready-To-Hand Equipment: A Dialectical View on the Existential Analytic
}

\section{La noción concreta de equipo listo para usar: una visión dialéctica de la analítica existencial}

\section{Artur Ravilevich Karimov}

Kazan Federal University, Kazan, Russia. Doctor of philosophy, Head of the department of Social Philosophy, Institute of Social and Philosophical Sciences and Mass Communications

$$
\text { ORCID ID 0000-0001-9245-2933 }
$$

\section{Aleksei Sergeyevich Guryanov}

Kazan State Power-Engineering University, Kazan, Russia. Kazan State Medical University, Kazan, Russia. Doctor of philosophy, associate professor of the department of Philosophy and Media

Communications, the department of History, Philosophy and Social studies

$$
\text { ORCID ID 0000-0002-0394-343X }
$$

\section{Elina Borisovna Minnullina}

Kazan State Power-Engineering University, Kazan, Russia. Doctor of philosophy, Head of the department of Philosophy and Media Communications ORCID ID: 0000-0003-1533-3361

* Correspondence

Email: arrkarimov@kpfu.ru

\section{Citation:}

Artur Ravilevich Karimov, Aleksei Sergeyevich Guryanov, Elina Borisovna Minnullina. (2021). The Concrete Notion of the Ready-ToHand Equipment: A Dialectical View on the Existential Analytic.

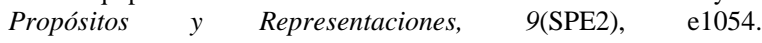
http://dx.doi.org/10.20511/pyr2021.v9nSPE2.1054 


\begin{abstract}
The article explores one of the aspects of Heidegger's existential analytic - everyday dealings with ready-to-hand equipment (tools). The author's aim is to analyze the phenomenon of equipment in a broader perspective to widen the borders of everyday being-in-the-world characterized by routine nonthematic dealings with things that distract man from his true being. The author claims that in everyday use man discovers only functionality of equipment which cannot be considered its genuine grasp. The actual knowledge of things is accessible mainly to their creators for whom they are not ready-to-hand tools but the aim of their thematic investigative thought. The concrete notion of a thing is developed by those who know the origin and formation of things. Accordingly, Dasein's everyday concern for the world is not the primary mode of being-in-the-world. The primary one is the master's non-daily creative work in his being-in-the-world which allows him/her to discover true being of things.
\end{abstract}

Keywords: everyday dealing, Dasein, concrete notion, historicity, ready-to-hand, creation, equipment

\title{
Resumen
}

El artículo explora uno de los aspectos de la analítica existencial de Heidegger: el trato diario con equipos (herramientas) listos para usar. El objetivo del autor es analizar el fenómeno del equipamiento en una perspectiva más amplia para ensanchar las fronteras del ser-en-el-mundo cotidiano caracterizado por un trato rutinario no temático con cosas que distraen al hombre de su verdadero ser. El autor afirma que en el uso cotidiano el hombre descubre únicamente la funcionalidad del equipo que no puede considerarse su genuino dominio. El conocimiento real de las cosas es accesible principalmente a sus creadores para quienes no son herramientas a mano, sino el objetivo de su pensamiento investigador temático. La noción concreta de cosa es desarrollada por quienes conocen el origen y la formación de las cosas. Por consiguiente, la preocupación diaria del Dasein por el mundo no es el modo principal de estar en el mundo. El principal es el trabajo creativo no diario del maestro en su ser-en-el-mundo que le permite descubrir el verdadero ser de las cosas.

Palabras clave: trato cotidiano, Dasein, noción concreta, historicidad, ready-to-hand, creación, equipamiento.

\section{Introduction}

Terminologically, the dialectical and phenomenological (hermeneutical) philosophical traditions intercross in the title of the research paper. G.V.F. Hegel and M. Heidegger as outstanding representatives of them were antagonists nearly in everything: from methodological principles and research issues to personal lifestyle; we know that Heidegger debated with Hegel throughout all his philosophical activity. It started with a course of lectures "Logic: The Question of Truth" given in the year of 1925 and shortly after that - his magnum opus "Being and Time" (1927). He began polemicizing with Hegel on the phenomenon of time and the difference between being and the presence of things and ended up disputing over metaphysics in the report "Hegel and the Greeks" delivered in 1958 and the seminar on "The Science of Logic" (1956/1957). According to Heidegger, Hegel's philosophy embodied the European metaphysical tradition that is characterized by a fundamental retreat from "original thinking" and an increasing oblivion of the question of the meaning of being, which was caused by treating entities as the main subject of philosophical reflection. Heidegger sees the return to the beginning (origin) of philosophical questioning and devaluation of the European philosophical tradition in the orientation to being-inspired thinking (denkerisches) compared to the Hegelian speculative approach symbolizing ratio-inspired thinking (denkendes) which has the opposite vector and aims at entities (things). V.V. Bibikhin, a Russian translator and expert in Heidegger, draws a similar distinction between "descending" and "ascending" vectors of the mind, respectively (Bibikhin, 2005). This difference in approaches is clearly expressed in Heidegger's lecture course "What is called thinking?" (1951/1952) - it is symbolic that he never used the term "concrete" while giving them (https://ebookppsunp.files.wordpress.com). Heidegger claimed that it is impossible to reach a higher 
"point of view" beyond the limits of Hegel's systematics (Heidegger, 2015). In this light, Heidegger sees his task not in finding particular faults and flaws in Hegel's system, but in discovering a hidden basis that Hegel ignored or omitted, or rather, that remained inaccessible to him due to his being bound with that very tradition. Heidegger was determined to "pull the rug from under that tradition". N.S. Plotnikov was fair to remark about Heidegger's long monologue against Hegel ending up with the last article of the German thinker "The End of Philosophy and the Task of thinking": thinking begins after the end of philosophy (http://www.ruthenia.ru). While Heidegger counted on being-oriented thinking to initiate "true thinking", we, being armed with ratio-oriented thinking, intend to find gaps in one of the parts of his existential analytic - in everyday work with stuff of various kinds or, in Heidegger's terminology, in dealings with ready-to-hand equipment/tools (Zeug).

\section{Methods}

In this work the authors intended to use dialectical methodology. Hegelian concrete thinking is distinguished by determination of consecutive historical and logical moments in the object's development right up to its present state and thus to ascend to the concrete. It may also be called a historical-genetic method for it allows one to trace the logic and history of particular phenomena as it is demonstrated in Hegel's essay "Who thinks abstractly?". For these reasons, the phenomenological/hermeneutical method of grasping the essence of things (equipment/tools) through their functionality is considered inadequate. Functionality is not sufficient for understanding what a thing is. The authors use dialectics to discover the essence of a ready-to-hand thing in the historical retrospective of its emergence and formation.

\section{Results and Discussion}

The existential analytic is known to split man's being into two types: our true being (also, existence as an experience of one's own finitude or anticipation of death) and its falling mode into our everyday, public lives. The latter is funded by being-in-the-world as one of the main existentials; a concern for the world or within-the-world entities is what characterizes Dasein "proximally and for the most part". Accordingly, everyday dealings with handmade within-the-world entities as equipment are the hallmarks of falling being.

Heidegger claims that equipment is disclosed in its references, and they are discovered in direct non-thematic dealings, in which equipment's particular towards-which (serviceability) is grasped. A person sees towards-which of entities in direct dealing with them. For instance, a specific towards-which of the bench is its intended use for sitting. And this towards-which of the bench is grasped spontaneously: seeing a bench, a tired man approaches it and sits down without any hesitation, thereby using it for its intended purpose. He does not have to ask himself what kind of object it is, for it is woven into a multitude of routine, everyday dealings man has with well-known entities around him; otherwise, the bench would become a subject of a particular thematic consideration.

In this light, nonthematic use of equipment is the more genuine, the simpler it is to deal with. Accordingly, the ready-to-hand is "the kind of being which equipment possesses - in which it manifests itself in its own right" (Heidegger, 1962). At the same time, the bench is woven into many other towards-which of entities that form a multitude of references: the bench is located in an open-air cinema; there are many other benches next to it; on one side there is a screen with its own towards-which; along the perimeter there are ice cream and fast food stalls that have their own assignment. This is how each thing is woven into an ensemble of references. Paul Gibbs writes about it: "For Heidegger the world is not an aggregate of "present-at-hand "objects that just occur, but a holistic context of relations" (Gibbs, 2010).

As we can see, Heidegger, as a matter of course, identifies towards-which of equipment (or serviceability - a term that he used in his later writings) with its in-itself: "Serviceability is that ground-trait out of which this being (dieses Seiende) looks to us, i.e. flashes and becomes present 
and so this being" (https://www.academia.edu). At this very point we detect a kind of weakness of the existential analytic.

Heidegger conceives discovery of itself of equipment as disclosure of functionality, which is also a meaning that equipment conveys to the user, or signification as Heidegger calls it. However, this approach in relation to equipment is obviously secondary. The primary one to the ready-to-hand is an act of signifying (bedeuten) performed in the process of creation of this thing. In the act of creation its author primarily signifies the thing that is subsequently perceived as signified by those who use it.

Heidegger focuses on the everyday life of man's within-the-world-being and invariably takes an individual out of the situation of signification formation. Indeed, the origin of things does not matter for everyday mass consciousness; it takes everything for granted, as J. Ortega-y-Gasset remarked. Mass Consciousness cares only about unrestrained consumption of the things designed by other people, it is interested in the variety of an assortment, it enjoys the comfort and abundance obtained from the hands of others: "... it was in the 19th century that the civilization allowed an average person to assert himself in the "surplus" world perceived as an abundance of benefits rather than concerns. He found himself among fabulous machines, miraculous medicines, helpful governments, cozy civil rights. However, he did not bother to think about the difficulties of design and production of these machines and medicines, he did not care about the vulnerability of the structure of society and state, and, careless of difficulties, he almost did not feel responsibility. Such a shift in balance cripples him and cuts off the life-giving roots" (http://lib.ru).

The author of "Being and Time" repeatedly refused to express any moral evaluation of the falling mode of existence, nevertheless, calling it "falling". In our opinion, the analytic of an everyday concern for entities within-the-world is an obvious existential funding of the consumer society, because ready-to-hand equipment includes lots of items - from hammers and benches (Heidegger's favourite examples) to, in a broad perspective, a multitude of things and services designed and produced to transport, cater and entertain people. Falling Dasein treats everything within-the-world as equipment that "equips" living and contributes to comfort and ease.

Though falling Dasein does not care about the origin of equipment used since it is already signified, the analysis of everyday existence cannot ignore what serves as a condition for everyday serviceability and primary signification. In our opinion, genuine disclosure of equipment is accessible for the one who initiates signification of entities, i.e. the one for whom it is not a tool for practical non-thematic use, but the purpose of theoretical interest that activates thought. In his work on the essence of techne, however, Heidegger opposes mass industrial production to original designe of things. G. V. Avdoshin writes in this regard: "With the appearance of machines, the poet recedes into the background... And if the poet lives in close relation with his work, the "machine" man has nothing to do with what he produces" (Avdoshin, 2013). In this light, only the poet in a broad sense, i.e. a creative person of great imaginative and expressive capabilities has a concrete notion of things; the one who makes use of it cannot develop such a notion, for since Plato's time, knowledge has been possessed only by those who can answer the question: "why is a thing the way it is?" Leibniz formulated that as the Ontological principle of sufficient reason: "... we can find no true or existent fact, no true assertion, without there being a sufficient reason why it is thus and not otherwise, although most of the time these reasons cannot be known to us" (https://plato.stanford.edu). Further he states that the principle of sufficient reason applies to all contingent truths as well as all necessary truths. It is obvious that the one who performs an act of creation in relation to equipment does know the reason.

As for the others, craftsmen who just reproduce entities can at best answer the question beginning with "how", and regular users grasp the entity's "towards-which". It is particularly evident with tools that have a bit more complex composition than a hammer or bench: the PC user has a vague idea of what this device really is; he cannot say what parts it consists of, how it is assembled and why so, and therefore, what the computer is in-itself (as such). In-itself of an artificial entity is best known to the one who designed it, not the one who merely uses it. J. Locke writes in his "Essay Concerning Human Understanding": "... Because an artificial thing being a production of 
man, which the artificer designed, and therefore well knows the idea of, the name of it is supposed to stand for no other idea, nor to import any other essence than what is certainly to be known, and easy enough to be apprehended.... " (https://oll.libertyfund.org). He knows it because he knows its origin and development, he is aware of its formation.

Concrete thinking in the Hegelian sense is distinguished by tracing the key consecutive transitions (moments) in the history of a thing; such an ascent (speculative sublimation) to concreteness using the historical-genetic method of research (as opposed to the method of the ascent from the abstract to the concrete applicable to classes of phenomena) allows us to follow and thereby reveal the definitive features of the thing which it acquires in the course of formation right up to its present state. The well-known Husserlian call "back to the things themselves" in this respect implies thinking based on the individual, unique circumstances of things' development; this kind of disclosure of things allows one to form a concrete and, therefore, correct judgment about them. In his famous essay "Who thinks abstractly?" Hegel gives the example of a murderer led to execution, around whom the crowd, divided in opinion, calls for instant execution and mercy. However, the only correct and concrete judgment can be developed by those who are really familiar with the circumstances of the criminal's life that led him to the scaffold: "One who knows men traces the development of the criminal's mind: he finds in his history, in his education, a bad family relationship between his father and mother, some tremendous harshness after this human being had done some minor wrong, so he became embittered against the social order..." (https://www.marxists.org). Although Hegel says that about people, this methodological approach is also effective in relation to equipment: the person who designed a product has an adequate idea of it - he knows how and why it appeared. Accordingly, to focus only on the everyday use of things means to artificially limit Dasein's ways of existence in being-in-the-world. Incidentally Heidegger admits that: "Equipment can genuinely show itself only in dealings cut to its own measure... but in such dealings an entity of this kind is not grasped thematically as an occurring Thing, nor is the equipment-structure known as such even in the using" (Heidegger, 1962). However, this idea has no further development.

It should be noted that in his later works ("The Question Concerning Technology", "The Origin of the Work of Art") Heidegger somewhat expands his view concerning the role of the ready-to-hand in the disclosure of things-in-themselves: with the increased role of enframing (Gestell) on the one hand and artistic creation on the other, the genuineness of grasping entities through serviceability is relegated to the background. In his later works Heidegger claims that genuineness of ready-to-hand tools is shown in the transforming uplifting image of the work of art rather than in dealings with them: "The work of art gave us to know what the shoe-tool is in truth" (https://www.academia.edu). Thus, Heidegger suggests another in-itself of things - the one disclosed by an artist.

In our opinion, with this second approach to the interpretation of in-itself of tools Heidegger confirms their creative nature ("...the tool is half thing, because determined through thingness, but still more; it is at the same time half artwork, and yet less, because it is without the self-sufficiency of the work of art" (https://www.academia.edu)), but leaps over the creative nature of the activity specific for a tool designer as well as a designer of anything else. If labor created man himself, the activity of objectification in all forms and socio-historical spheres (not only in the area of material production) allowed him not only to materialize himself in his creations and thus change the world around him, but also to gain an understanding of what he does in the act of free, inalienable creativity (Guryanov, 2012).

\section{Summary}

We showed that (1) M. Heidegger's existential analytic intentionally narrows the field of research on the issue of dealings with ready-to-hand entities limiting it to everyday routine that is taken out of their formation context; Dasein discovers serviceability of things and is not concerned about their origin, for in the falling mode Dasein merely encounters things as present-at-hand. (2) Everyday dealings with the within-the-world entities are not the primary way of dealings inherent in being-in-the-world since non-thematic grasp of "significance" of equipment is historically and 
logically preceded by an act of signification from the part of those who design and create things. The existential analytic leaves the genesis of ready-to-hand things in obscurity, but the master's activities spotlight the development of things for writing, sitting, sewing, working, etc. The master is the one who introduces something into the world and thus creates and bestows his creations upon humankind. (3) It affects the interpretation of itself of produced things grasped as their functionality by Dasein. The user's non-thematic grasp of things is fundamentally different from the creator's thematic grasp, for the author is aware of the origin and the process of historical and logical formation of things. The ascent to the concrete accompanies creative work and allows the originator to form a concrete idea of designed things - creation of things is congruent with their cognition. Real itself of equipment is accessible to the master who knows "why" and "how" of things.

\section{Conclusion}

A phenomenological way of looking at things affects the formulation of the question about ready-to-hand equipment and the whole exposition of the research problematics. As a result of phenomenological reduction, the existential analytic discovers true existential being-to-death but abstractly opposes it to its falling mode of everyday activities. Hegel claimed that contradiction is the truth of everything there is, but it must as well be resolved by positing a third element, which, in our case, is non-daily within-the-world-being of the master that creates our life-world. A master's concern for entities is of another kind - it is not an escape in the face of death to remain safe and free from anxiety. Master's activity overcomes death anxiety within the world as it requires great personal sacrifice regardless of what his creations are - tools, devices, pictures or books. Creative work disclose true being of things.

\section{Acknowledgement}

The work is performed according to the Russian Government Program of Competitive Growth of Kazan Federal University.

\section{References}

Avdoshin, G.V. (2013). The seen and its presentational modes in arts. Kazan: KGEU Publ.

Bibikhin, V.V. (2005). Heidegger: from "Being and time" to "Beitrage". Voprosy filosofii, 4, 114-129.

Gegel, G.W.F. Who thinks abstractly? URL: https://www.marxists.org/reference/archive/hegel/works/se/abstract.htm

Gibbs, P. (2010). Heidegger's contribution to the understanding of work-based studies. Springer Science \& Business Media.

Guryanov, A.S. (2012). Creativity as a dialectical non-everyday dimension of the totality of being-in-the-world in the context of Heidegger's existential analytics. Historical, Philosophical, Political, and law Sciences, Cultural and Arts Studies. Questions of theory and practice, 11(25), 72-76.

Heidegger, M. (1962). Being and time. Blackwell Publishers Ltd.

Heidegger, M. (2015). Negativity: A confrontation with Hegel approached from negativity. Saint-Petersburg: Vladimir Dal Publ.

Heidegger, $M$. The origin of the work of art. URL: https://www.academia.edu/2083177/The_Origin_of_the_Work_of_Art_by_Martin_Heideg ger

Heidegger, M. What is called thinking? URL: https://ebookppsunp.files.wordpress.com/2016/06/martin_heidegger_j-_glenn_gray_transl ator_frebookfi-org.pdf

Leibnitz, G.W. Principle of Sufficient Reason. Stanford Encyclopedia of Philosophy URL: https://plato.stanford.edu/entries/sufficient-reason/

Locke, J. Essay concerning human understanding. URL: https://oll.libertyfund.org/titles/locke-the-works-vol-1-an-essay-concerning-human-underst anding-part-1 
Ortega-y-Gasset, J. The revolt of the masses. URL: http://lib.ru/FILOSOF/ORTEGA/ortega15.txt_with-big-pictures.html

Plotnikov, N.S. The absolute spirit and the other beginning. Hegel and Heidegger. URL: http://www.ruthenia.ru/logos/personalia/plotnikov/articles/02_band68.html 